\title{
KEBIJAKAN PEMERINTAH DAERAH DALAM \\ PERLINDUNGAN MASYARAKAT ADAT DI PROVINSI BANTEN: STUDI KASUS MASYARAKAT ADAT BADUY DAN CITOREK
}

\section{LOCAL GOVERNMENT POLICY TO THE INIDIGENOUS PEOPLE PROTECTION IN PROVINCE OF BANTEN: CASE STUDY ON INDIGENOUS POEPLE OF BADUY AND CITOREK}

\author{
Muhlisin $^{1)}$, Helmy Faizi Bahrul Ulumi²), dan Ayatullah Humaeni'2) \\ ${ }^{1)}$ Badan Perencanaan dan Pembangunan Daerah Provinsi Banten \\ J1. Syech Nawawi Al Bantani, (KP3B) Serang, Banten \\ Tlp. (0254) 267053 fax. (0254) 267052 \\ ${ }^{2)}$ Laboratorium Bantenologi UIN Sultan Maulana Hasanuddin Banten \\ J1. Jendral Sudirman No.30 Serang - Banten 42118 \\ E-mail: muhlisinsidik@gmail.com
}

\begin{abstract}
ABSTRAK
Perlindungan terhadap masyarakat adat terpencil dewasa ini masih sekadar menganggap masyarakat adat terpencil sebagai suku terasing yang merupakan aset budaya yang harus dilindungi tanpa melihat adanya penghormatan terhadap hak-haknya. Kabupaten Lebak sudah memiliki dua peraturan daerah yang berkaitan dengan perlindungan masyarakat adat Baduy dan Kasepuhan Banten Kidul. Namun demikian, belum ada payung hukum di tingkat Provinsi Banten baik berupa Peraturan Daerah (Perda) maupun Peraturan Gubernur (Pergub) yang mengatur tentang Masyarakat Hukum Adat. Selain itu pula belum ada pedoman pelaksanaan untuk kedua payung hukum tersebut, sehingga payung hukum yang ada belum mangokomodir keseluruhan permasalahan yang dihadapi oleh masyarakat adat yang kompleks. Untuk mengetahui kebijakan Daerah mengenai perlindungan masyarakat adat dilakukan penelitian dengan menggunakan metode deskriptif kualitatif melalui studi kepustakaan dan wawancara. Pengambilan data lapangan dilakukan pada 15 Mei - 15 Juli 2016 di Desa Kanekes dan Kasepuhan Citorek dengan mewawancari 13 informan kunci. Hasil studi menunjukkan bahwa secara umum, perhatian pemerintah Kabupaten Lebak terkait masyarakat adat/kasepuhan sudah dilakukan dengan mengeluarkan dua Perda dan Peraturan Desa Kanekes. Namun, Perda terkait masyarakat Baduy baru mengakomodir masalah hak ulayat, belum pada hal-hal lain yang sebenarnya sangat krusial dan perlu segera diatasi. Masyarkat Baduy dan Masyarakat Kasepuhan Citorek secara umum menilai bahwa dua Perda tersebut sudah membantu mengatasi permasalahan yang ada, walaupun dalam tataran teknis masih ditemui beberapa permasalahan. Masyarakat adat/kasepuhan berharap ada Perda lain yang dapat mengatasi berbagai permasalahan yang muncul terkait masyarakat adat. Selain itu juga pemerintah perlu proaktif mengawal iplementasi Perda tersebut.
\end{abstract}

Kata Kunci: Kebijakan pemerintah daerah, masyarakat adat Baduy, Kasepuhan Citorek. 


\section{ABSTRACT}

Indigenous people are considered as cultural assets that need be protected regardless of their respectful rights. There are two indigenous communities In Banten Province, Lebak Regency in particular, Baduy and Kasepuhan Banten Kidul. While Lebak Regency has two local regulations related to the protection of these indigenous communities, there are no regulations at the provincial level. In addition, there are no operational guidelines to implement those two existing local laws. As a result, the regulations have been unable to accommodate the complex problems faced by the indigenous communities. In relation to indigenous communities 'protection, this research aims to examine the current local and provincial government policies utilising a qualitative-descriptive method through literature study and interview. Field data was collected during May to July 2016 in Kanekes Village and Kasepuhan Citorek by interviewing 13 key informants. The study found that Lebak Regency has issued two local regulations related to indigenous communities/kasepuhan protection, in addition to Kanekes Village Regulation. The regulations related to Baduy society, however, barely accommodate the issue of ulayat rights, not on broader issues that are actually very crucial and need to be addressed. Despite some problems in the implementation level, the Baduy and Kasepuhan Citorek societies generally consider that the two existing local regulations are beneficial. The Indigenous communities/ kasepuhan, furthermore, hope that there are another laws for other various problems that arise related to indigenous peoples. In addition, the local and provincial governments also need to be more active in guarding the implementation of the laws.

Keywords: local government policy, Baduy indigenous pople, Kasepuhan Citorek.

\section{PENDAHULUAN}

Sejak akhir tahun 90-an, perhatian terhadap masyarakat adat mulai menyeruak khususnya bagi masyarakat adat terpencil di Indonesia. Perhatian tersebut antara lain adalah perubahan istilah negatif suku terasing dan masyarakat terbelakang menjadi komunitas masyarakat terpencil atau masyarakat adat terpencil. Selain itu, perhatian tersebut ditunjukkan dengan adanya pengakuan dari pemerintah yang berupa: 1) pengakuan eksistensi komu-nitas; 2) hak sosial dan ekonomi komunitas adat terpencil; 3) perlindungan tradisi dan adatistiadat; dan 4) pengakuan terhadap program pemberdayaaan komunitas adat terpencil.

Masyarakat adat atau tepatnya disebut masyarakat hukum adat adalah komunitas manusia yang patuh pada peraturan atau hukum yang mengatur tingkah laku manusia dalam hubungannya satu dengan yang lainnya, berupa keseluruhan dari kebiasaan dan kesusilaan yang benar-benar hidup karena diyakini dan dianut, yang jika dilanggar pelakunya mendapat sanksi dari penguasa adat (Samosir, 2013; Arizona, 
2016). Suatu komunitas dikatakan sebagai masyarakat adat bila warganya memiliki perasaan kelompok (in-group feeling), adanya pranata pemerintahan adat; adanya harta kekayaan dan/atau benda-benda adat; dan adanya perangkat norma hukum adat. Khusus pada kesatuan masyarakat hukum adat yang bersifat territorial juga terdapat unsur adanya wilayah tertentu (Bahar, 2008).

Perlindungan terhadap masyarakat adat terpencil khususnya dalam keberpihakan hukum Indonesia masih sekadar menganggap masyarakat adat terpencil sebagai suku terasing yang merupakan aset budaya Indonesia yang harus dilindungi tanpa melihat adanya penghormatan terhadap hak-hak masyarakat adat sebagai warga negara Indonesia yang seharusnya mendapat porsi yang sama di mata hukum dan instrumen hukum lainnya seperti masyarakat Indonesia yang lain. Pelanggaran dan pelecehan terhadap hak-hak ulayat masyarakat adat masih sering saja terjadi, dan justru hal tersebut dilakukan oleh pihak-pihak yang merasa dirinya berpendidikan dan jauh dari keterbelakangan.

Keberadaan komunitas masyarakat adat sebenarnya telah mendapat porsi hukum dalam setiap instrumen hukum nasional bahkan internasional, namun masih banyak perdebatan dan tafsir terhadap isi dan pelaksanaan terhadap pasal-pasal yang mengatur penghormatan, pengakuan dan perlindungan tentang hak dan kewajiban masyarakat adat sebagai bagian dari warga Negara Indonesia.

Lahirnya Undang-Undang No. 6 Tahun 2014 tentang Desa, merupakan angin segar bagi pengakuan masyarakat adat yang mendiami nusantara ini. Di samping desa, dalam UU 6/2014, juga diakui adanya Desa Adat. Pemerintah daerah dapat melakukan penataan kesatuan masyarakat hukum adat dan menetapkannya menjadi Desa Adat melalui sebuah peraturan daerah. Asalkan tiga kriteria Desa Adat terpenuhi, yakni kesatuan masyarakat hukum adat beserta hak tradisionalnya secara nyata masih hidup, dan sesuai dengan perkembangan masyarakat serta sejalan dengan prinsip Negara Kesatuan Republik Indonesia.

Di samping itu, terbitnya Permendagri No. 52 Tahun 2014 tentang Pedoman Pengakuan dan Perlindungan Masyarakat Hukum Adat, dapat dijadikan acuan bagi kepala daerah untuk memberikan pengakuan dan perlindung-an masyarakat hukum adat. Dengan adanya kedua payung hukum nasional maka bagi pemerintah daerah disarankan untuk disegerakan memiliki kebijakan terhadap pengakuan dan 
perlindungan terhadap masyarakat adat.

Provinsi Banten memiliki masyarakat adat Baduy dan 522 masyarakat kasepuhan yang tersebar di beberapa kecamatan dan desa di Kabupaten Lebak. Semua masyarakat adat dan kasepuhan ini masih hidup dan memilki karakteristik dan keunikan historis dan budayanya masing-masing (Perda No.8/ 2015). Kabupaten Lebak sudah memiliki Perda No. 8/2015 tentang Pengakuan, Perlindungan dan Pemberdayaan Masyarakat Hukum Adat Kasepuhan , dan Perda No.32/ 2001 tentang Perlindungan atas Hak Ulayat Masyarakat Baduy. Namun demikian, belum ada payung hukum di tingkat Provinsi, belum ada Perda/Pergub yang mengatur tentang Desa Adat/Masyarakat Hukum Adat, dan belum ada pedoman pelaksanaan untuk kedua payung hukum tersebut. Di samping itu, payung hukum yang ada belum mangokomodir keseluruhan permasalahan yang dihadapi oleh masyarakat adat yang kompleks. Berdasarkan latar belakang tersebut, adalah penting untuk mengkaji mengenai kebijakan perlindungan masyarakat adat di Provinsi Banten untuk memahami hak-hak dan kebutuhan masyarakat adat dalam mewujudkan keberadaannya.

\section{METODE PENELITIAN}

Penelitian ini menggunakan metode deskriptik kualitatif. Penelitian idilakukan di masyarakat adat Baduy dan masayarakat Kasepuhan/Wewengkon Citorek pada tanggal 15 Mei - 15 Juli 2016. Data diperoleh melalui studi kepustakaan dan wawancara langsung terhadap tigabelas informan kunci yang mengetahui permasalahan masyarakat adat baik di Baduy maupun Citorek (Tabel 1).

Teknik analisis data yang digunakan dalam penelitian ini adalah dengan menggunakan metode analisis kualitatif, yakni data yang diperoleh dari hasil penelitian dipilih dan diseleksi berdasarkan kualitas dan kebenarannya sesuai dengan relevansinya dengan materi penelitian, untuk kemudian disusun secara sistematis dan dikaji dengan metode berfikir deduktif untuk menjawab permasalahan yang diajukan (Soekanto, 2012).

\section{HASIL DAN PEMBAHASAN}

\section{Gambaran Umum Masyarakat Adat di}

\section{Provinsi Banten}

Provinsi Banten memiliki masyarakat adat Baduy dan Kasepuhan Banten Kidul yang seluruhnya berada di Kabupaten Lebak. Masyarakat adat Baduy berada di Desa Kanekes, Kecamatan Leuwidamar. Sementara Kasepuhan Banten Kidul berada di Kecamatan Cibeber dan di wilayah Kabupaten Sukabumi Provinsi Jawa Barat. 
Tabel 1. Informan Kunci Masyarakat Adat Baduy dan Citorek

\begin{tabular}{clcl}
\hline No. & Informan & Umur (th) & Keterangan \\
\hline 1. & Ahmadi & 45 & Tokoh masyarakat Citorek Barat \\
2. & K.H. Marzuki & 46 & Tokoh Agama \\
3. & Aki Calo & 80 & Kasepuhan Kampung Ciusul Citorek Kidul \\
4. & Edih Mulyadi & 45 & Jaro Baduy \\
5. & Sarnuki & 45 & Carik Kanekes \\
6. & H. Ace & 58 & Anggota DPRD Kab. Lebak \\
& & & (Tokoh Masyarakat Kasepuhan Citorek) \\
7. & Jaih & 35 & Ciusul, Citorek Kidul \\
8. & Jajang & 40 & Kepala Desa Citorek Timur \\
9. & Jaro Narta (Atok) & 40 & Ciusul, Citorek Sabrang \\
10. & Muh. Nur & & Sekdes Citorek Timur \\
11. & Odih & 37 & Cipulus, Citorek Kidul \\
12. & Remayudin & 50 & Citorek Barat \\
13. & Ust. Zurjani & 32 & Citorek Sabrang \\
\hline
\end{tabular}

\section{Masyarakat Adat Baduy}

Masyarakat Adat Baduy berada di Desa Kanekes, Kecamatan Leuwidamar Kabupaten Lebak. Secara geografis terletak pada koordinat 6 ${ }^{\circ} 27^{\prime} 27^{\prime \prime}-6^{\circ} 30^{\prime} 0^{\prime \prime} \mathrm{LS}$ dan $108^{\circ} 3^{\prime} 9^{\prime \prime}-106^{\circ} 4^{\prime} 55^{\prime \prime}$ BT (Perdes Kanekes No. 01 2007). Mereka bermukim tepat di kaki pegunungan Kendeng pada ketinggian 300 - $1200 \mathrm{~m}$ dpl yang berbukit dan bergelombang dengan kemiringan tanah ratarata mencapai $45 \%$. Tipe tanahnya adalah vulkanik (di bagian Utara), tanah endapan (di bagian Tengah), dan tanah campuran (di bagian selatan). Suhu berkisar antara $16^{\circ} \mathrm{C}$
$-30{ }^{\circ} \mathrm{C}$ dengan suhu udara rata-rata $20^{\circ} \mathrm{C}$ (Suparmini, Setyawati, dan Sumunar, 2012). Secara adminitrasif Desa Kanekes diapit oleh 11 desa dari 6 kecamatan: Sebelah Utara berbatasan dengan Desa Bojongmenteng, Desa Cisimeut Raya dan Desa Nayagati (Kecamatan Leuwidamar). Sebelah Barat berbatasan dengan Desa Parakan Besi, Desa Kebon Cau (Kecamatan Bojongmanik) dan Desa Karang Nunggal (Kecamatan Cirinten). Sebelah Selatan berbatasan dengan Desa Cikate dan Desa Mangunjaya (Kecamatan Cijaku). Sebelah Timur berbatasan dengan Desa 
Karangcombong (Kecamatan Muncang),

Desa Hariang dan Desa Cicalebang (Kecamatan Sobang).

Masyarakat Adat Baduy dibedakan menjadi Baduy Dalam (Baduy Kajeroan) dan Baduy Luar (Panamping). Baduy Dalam menempati sekitar 30\% wilayah Baduy, terdiri dari tiga kampung, yaitu: Cibeo,
Cikatarwana dan Cikeusik. Baduy Luar memiliki sekitar 49 kampung yang menempati areal sisanya yang langsung berbatasan dengan dunia luar. Selain kampung-kampung tersebut terdapat wilayah yang disebut Babakan dan Tanah Dangka.

Babakan merupakan perkampungbaru yang dibentuk apabila jumlah populasi

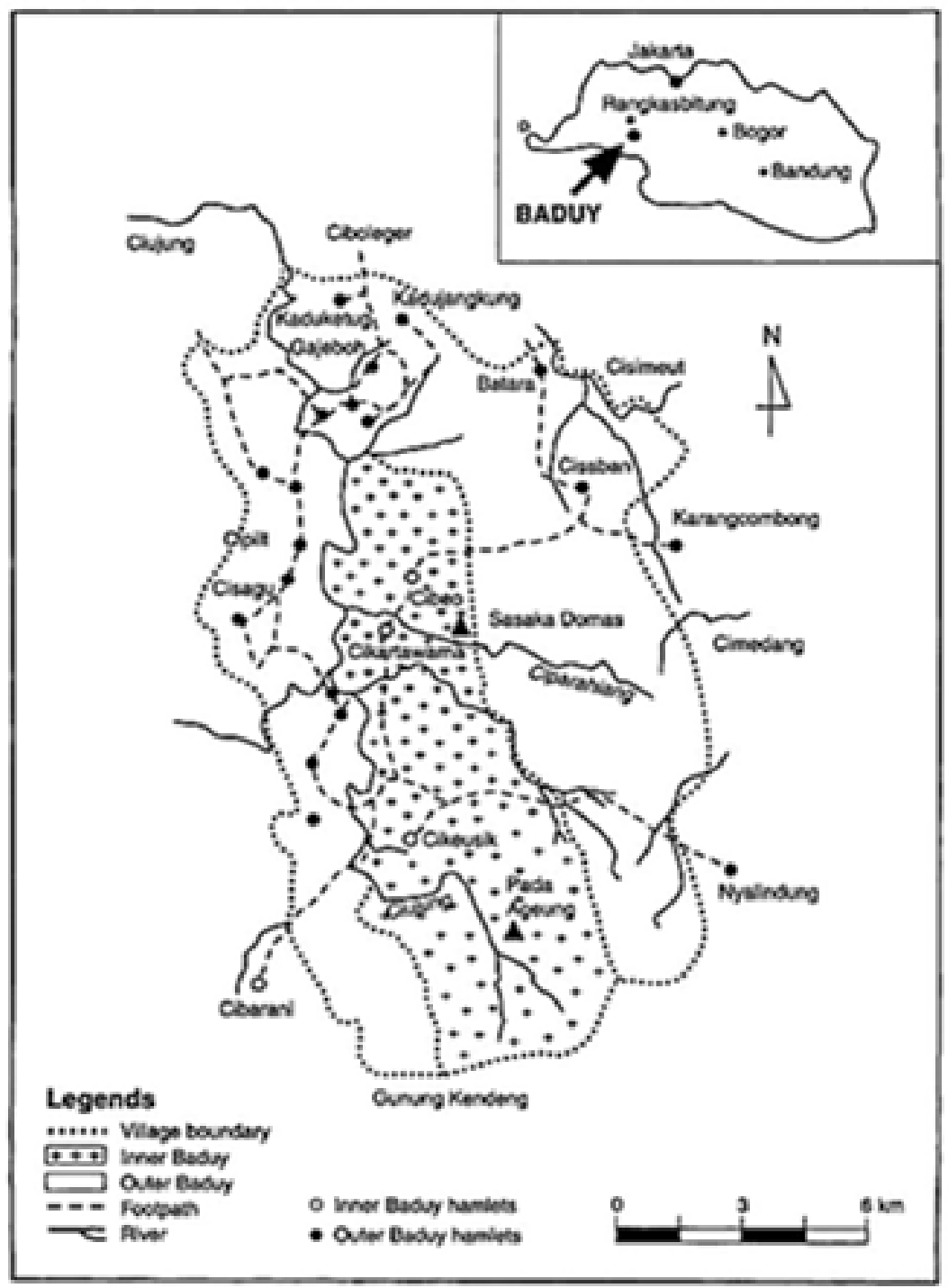

Gambar 1. Peta Wilayah Masyarakat Adat Baduy di Kabupaten Lebak Provinsi Banten (Sumber: Iskandar, 1999) 
dari kampung yang ada sudah melebihi batas populasi yang ditentukan. Sedangkan Tanah Dangka (disebut Kampung Dangka) adalah areal yang secara administratif berada di luar wilayah Desa Kanekes, yang secara umum penduduknya masih memiliki keterikatan kekerabatan dan kosmik dengan warga serta tata aturan dan sistem yang berlaku di Tatar Kanekes (Perdes Kanekes No. 01 2007). Kampung Dangka menurut Hakim (2012) adalah kampung tempat pengasingan pelanggar adat. Tetapi menurut Permana (2010), Kampung Dongka merupakan buffer zone atas pengaruh dari luar.

Masyarakat Baduy Dalam sangat kokoh mempertahankan adat kebiasaanya dibandingkan dengan Baduy Luar. Mereka menolak budaya luar yang tidak sesuai dengan adat istiadatnya dan senantiasa memegang teguh aturan-aturan adat (pikukuh) yang diwariskan oleh leluhurnya. Mereka pantang (teu wasa) untuk mengubahnya. Mereka juga sangat berhatihati dalam memperlakukan lingkungannya, dan sangat memperhatikan keberlanjutan lingkungan alam tersebut (Danasasmita dan Djatisunda. 1984)

Menanam padi di huma adalah mata pencaharian utama masyarakat Baduy, baik yang tinggal di kampung dangka, penamping maupun kejeroan. Selain itu yang menjadi mata pencaharian masyarakat Baduy di Desa Kanekes adalah membuat hasil tenun, anyaman bambu, dan atap kiray, serta menjual hasil hutan ke luar wilayah desanya.

Pakaian Masyarakat Baduy Dalam terdiri dari baju (jamang) berwarna putih, sarung tenun hitam bergaris putih (samping aros), dan ikat kepala warna putih (telekung), sabuk putih, dan gelang benang (gelang kanteh). Sedangkan Baduy Luar selalu mengenakan kemeja kamprét dua rangkap (warna putih di dalam dan warna hitam di luar), sarung poléng hideung dengan ikat pinggang adu mancung, dan ikat kepala yang terbuat dari kain mérong yang bermotif batik warna biru gelap (lomar atau romal). Sekarang, banyak lelaki Baduy yang mengenakan celana berjahit sebatas lutut.

Bahasa yang digunakan Masyarakat Adat Baduy adalah Sunda Kuno yang tak mengenal tingkatan tata bahasa. Sementara itu, kepercayaannya adalah beriman kepada Allah dalam naungan Agama Sunda Wiwitan. Mereka menyebutnya Batara Tunggal (Tuhan Yang Maha Esa), Batara Jagat (Penguasa Alam), dan Batara Seda Niskala (Yang Gaib). Mereka juga mempercayai Sang Hiyang Keresa (Yang Maha Kuasa) atau Nu Ngersakeun (Yang Menghendaki) sebagai pemegang kekuasaan tertinggi. Tuhan Sunda Wiwitan bersemayam 
di Buana Nyungcung (Dunia Atas). Bahkan diyakini semua Dewa Agama Hindu tunduk terhadap Batara Seda Niskala (Wahid, 2011; Sucipto dan Limbeng. 2007).

\section{Kasepuhan Banten Kidul}

Kasepuhan Banten Kidul adalah kelompok masyarakat adat sub etnis Sunda yang tinggal di sekitar Gunung Halimun, terutama di wilayah Kabupaten Sukabumi sebelah barat hingga ke Kabupaten Lebak, dan ke utara hingga ke Kabupaten Bogor. Kasepuhan merujuk pada adat istiadat lama yang masih dipertahankan dalam kehidupan sehari-hari. Masyarakat Kasepuhan Banten Kidul meliputi beberapa desa tradisional dan setengah tradisional, yang masih mengakui kepemimpinan adat setempat. Terdapat beberapa Kasepuhan di antaranya adalah Kasepuhan Ciptagelar, Kasepuhan Cisungsang, Kasepuhan Cisitu, Kasepuhan Cicarucub, Kasepuhan Citorek, serta Kasepuhan Cibedug. Kasepuhan Ciptagelar sendiri melingkup dua Kasepuhan yang lain, yakni Kasepuhan Ciptamulya dan Kasepuhan Sirnaresmi (Buku Kepustakaan Online, 2017).

Salah satu keasepuhan Banten Kidul yang berperan penting di Kabupaten Lebak adalah Wewengkon Adat Kasepuhan Citorek. Kasepuhan Citorek secara admin- istratif berada di kecamatan Cibeber, Kabupaten Lebak. Wilayah ini dikelilingi ooleh Taman Nasional Gunung Halimun Salak (TNGHS), berbatasan dengan Kabupaten Bogor, Provinsi Jawa Barat dan Kecamatan Sobang, Kabupaten Lebak Provinsi Banten.

Setelah mengalami beberapa kali pemekaran menjadi lima desa, yaitu: Citorek Timur, Citorek Tengah, Citorek Barat, Citorek Kidul dan Citorek Sabrang. Dari kelima desa tersebut yang paling istimewa adalah Citorek Timur, karena tempat Kasepuhan Kaolot (Pupuhu) sehingga setiap acara besar diselenggarakan di Desa Kaolotan Citorek Timur seperti Seren Taun, Hajatan Masal, dan sebagainya.

Luas Desa Citorek Timur sekitar 1.712,4 Ha, yang terdiri dari pesawahan, pesawahan 24,8 Ha, perkebunan $129 \mathrm{Ha}$,

kehutanan 1326,25 Ha, perkantoran 0,25 Ha, dan komplek pemakaman 0.32 Ha. Sebelah Utara Desa Citorek Timur berbatasan dengan Desa Suka Maju kecamatan Sobang, sebelah Timur berbatasan dengan Kabupaten Bogor Provinsi Jawa Barat, Sebelah Barat berbatasan dengan Citorek Tengah, Sebelah Selatan Berbatasan dengan Citorek Sabrang. Jumlah penduduk desa Citorek Timur adalah 2685 jiwa, terdiri dari 1320 
perempuan dan 1365 laki-laki. Penduduk Desa Citorek adalah mayoritas pribumi, walaupun ada beberapa penduduk pendatang lebih karena pekerjaan dan perkawinan yang menyebabkan mereka tinggal di desa tersebut. Di sisi lain penduduk Citorek juga ada yang tinggal di luar Desa Citorek juga karena alasan pekerjaan dan perkawinan, tapi tetap masih merasa terikat dengan adat istiadat, sehingga ketika Upacara Seren Taun mereka berusaha berkunung ke desa asalanya.

Bentuk rumah masyarakat Citorek sudah banyak yang menggunakan batu-bata

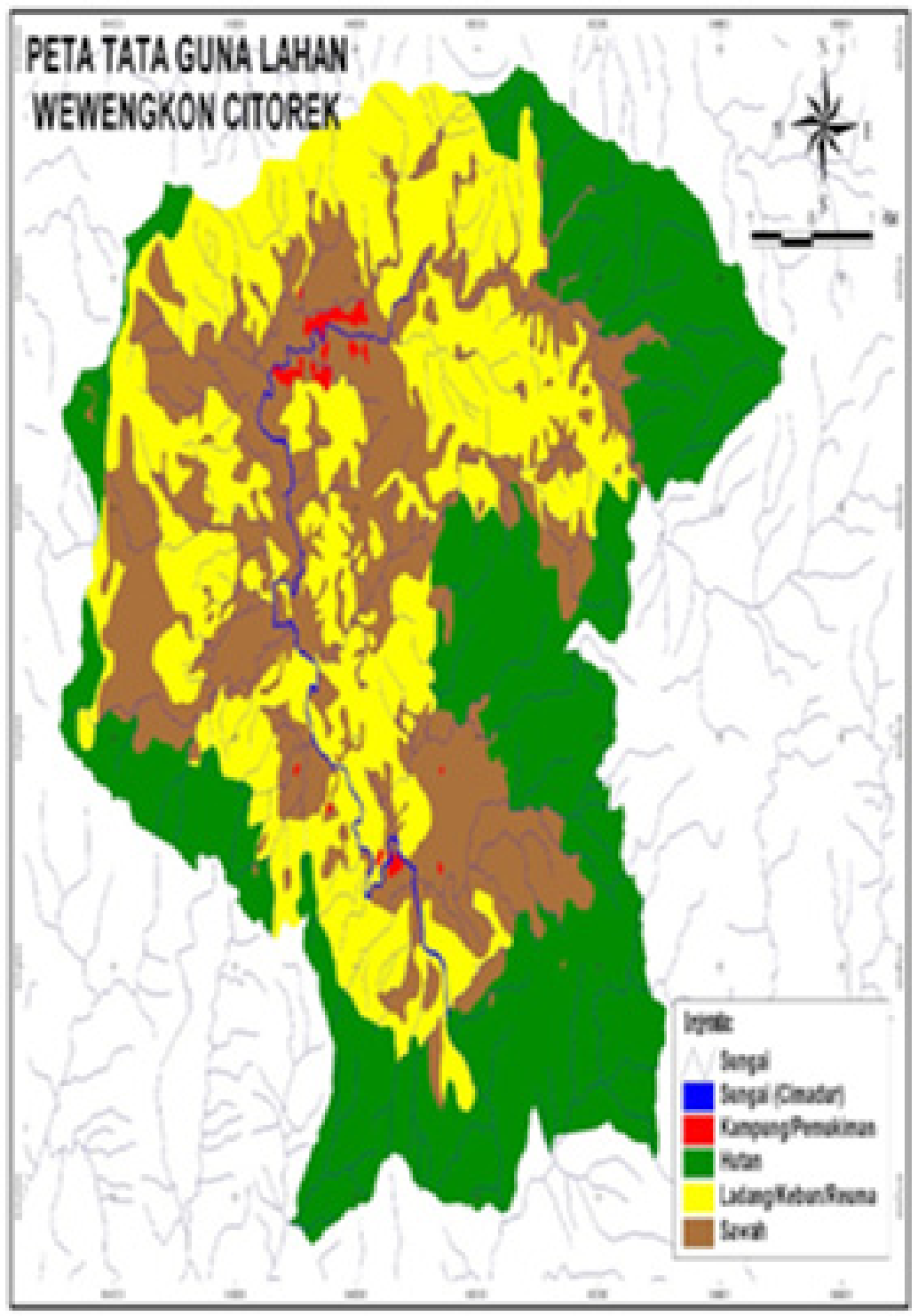

Gambar 2. Peta Wilayah Wewengkon Citorek

(Sumber: Lampiran II Perda Kab. Lebak No. 08 Tahun 2015) 
seiring dengan pembangunan sarana transportasi. Meskipun begitu masih ada beberapa rumah yang mempertahankan bentuk dan corak rumah dulu. Rumah tersebut merupakan rumah yang terbuat dari hasil hutan masyarakat setempat, seperti kayu, bambu, daun kelapa/daun kirai. Rumah Masyarakat Adat Citorek disebut juga dengan Rumah Panggung.

Desa Citorek secara adat dipimpin oleh satu orang kasepuhan yang tinggal di Citorek Timur. Kasepuhan mempunyai perwakilan Setiap Desa yang disebut gurumulan. Struktur kasepuhan pada dasarnya mirip dengan dengan struktur desa, yaitu: kasepuhan sebagai kepala adat, kemudian dibawah kasepuhan ada keamanan adat, pangulu, jaro adat, baris kolot (perangkat adat), ronda adat yang bertugas keamanan kampung, dan indung beurang atau paraji.

Mata pencaharian masyarkat Citorek pada umumnya adalah petani. Selain petani ada yang pedagang, penambang emas. Di antara mereka ada juga yang berjualan keluar wilayah Desa Citorek, seperti jualan tudung, dan lain-lain. Petani di Citorek adalah petani adat yang tidak memperhitungkan keuntungan dan kerugian. Setiap masyarakat harus mempunyai minimal satu lumbung padi, sebagai persediaan masyarakat setelah panen.

Bagi masyarakat Citorek, padi sangat pantang dijual, termasuk menjual nasi. Hal ini sebagai antisipasi untuk menjaga kekurangan stok bahan makanan pokok, sehingga terhindar dari bencana kelaparan. Masyarakat boleh menjual padi atau beras, tapi dari sisa hasil panen sebelumnya.

Salah satu ritual masyarakat adat Banten Kidul setelah panen padi adalah Seren Tahun yang didahului dengan ritual "Serah ponggokan" sebagai bentuk perwujudan permintaan maaf kepada Bumi sebagai ibu yang telah digali, dicangkul, dibakar, dan dibajak. Semua kegiatan ini berhubungan dengan cara-cara bertani, mengolah lahan/tanah yang dilakukan oleh masyarakat adat, dan diakhiri dengan upacara syukuran kepada Sang Pencipta yang telah memberikan rejeki, sehingga kegiatan pertanian berhasil dengan baik (Suganda, 2015).

\section{Kebijakan Pemerintah Daerah dalam Perlindungan Masyarakat Adat}

Kebijakan pemerintah merupakan kebijakan publik, yang merupakan sejumlah aktivitas pemerintah untuk memecahkan masalah di masyarakat, baik secara langsung maupun melalui lembaga yang mempengaruhi kehidupan masyarakat. 
Pengaruh dari tindakan atau aktivitas pemerintah tersebut ialah: adanya pilihan kebijakan yang dibuat, output kebijakan, dan dampak kebijakan yang mempengaruhi kehidupan masyarakat (Tangkilisan, 2003). Kebijakan pemerin-tah daerah yang diharapkan oleh masyarakat adat adalah dalam perlindungan hak-hak masyarakat adat.

Hak-hak Masyarakat Kasepuhan yang harus diakui, dihormati, dilindungi, dan dipenuhi oleh Pemerintah Daerah menurut Perda Kabupaten Lebak No 8 Tahun 2015 adalah: 1) hak ulayat; 2) hak perorangan warga Kasepuhan atas tanah dan sumber daya alam; 3) hak memperoleh pembagian manfaat dari sumber daya genetik dan pengetahuan tradisional oleh pihak luar; 4) hak atas pembangunan; 5) hak atas spiritualitas dan kebudayaan; 6) hak atas lingkungan hidup; 7) hak untuk mendapatkan layanan pendidikan khusus; 8) hak untuk mendapatkan layanan kesehatan; 9) hak untuk mendapatkan layanan administrasi kependudukan; 10) hak untuk mengurus diri sendiri; 11) hak untuk menjalankan hukum dan peradilan adat; 12) hak untuk didengar aspirasinya dalam penyelenggaran pemerintahan desa dan pemilihan kepala desa; dan 13) hak-hak lain yang diatur dalam peraturan perundang-undangan.
Hak atas tanah dan sumber daya alam merupakan salah satu hak paling penting bagi masyarakat adat sebab keberadaan hak tersebut menjadi salah satu ukuran keberadaan suatu komunitas masyarakat adat (Arizona, 2010). Sedangkan Nababan (2009) menyebutkan dari sekian banyak kategori hak yang berhubungan dengan masyarakat adat, setidaknya ada empat hak masyarakat adat yang paling sering disuarakan, antara lain: 1) Hak untuk "menguasai” (memiliki, mengendalikan) dan mengelola (menjaga, memanfaatkan) tanah dan sumber daya alam di wilayah adatnya; 2) Hak untuk mengatur diri sendiri sesuai dengan hukum adat (termasuk peradilan adat) dan aturan-aturan adat yang disepakati bersama oleh masyarakat adat; 3) Hak untuk mengurus diri sendiri berdasarkan sistem kepengurusan/ kelembagaan adat; dan 4) Hak atas identitas, budaya, sistem kepercayaan ('agama'), sistim pengetahuan (kearifan tradisional) dan bahasa asli. Di tingkat Internasional, persoalan hak atas tanah dan sumber daya alam ini sudah diatur dalam United Nation Declaration on the Right of Indigenous Peoples (UNDRIP) tahun 2007. Demikian pula pada tataran nasional hak-hak masyarakat adat juga sudah diatur oleh undang-undang seperti yang ditunjukkan oleh UU Pemerintahan Daerah, UU HAM, UU Kehutanan, UU Sumber Daya 
Air, UU Perkebunan, UU Pengelolaan

Wilayah Pesisir dan Pulau-pulau Kecil, dan

UU Perlindungan dan Pengelolaan Lingkungan Hidup.

Di tingkat Provinsi Banten belum ada aturan-aturan khusus mengenai masyarakat adat. Namun demikian setidaknya ada Rancangan Peraturan Daerah Provinsi Banten mengenai Budaya Daerah 2015 yang mengarah pada perlindungan masyarakat adat. Pasal yang menyentuh pada perlindungan masyarakat adat pada Raperda Budaya Daerah tersebut antara lain adalah:

\section{Pasal 13}

(1) Penyelenggaraan kebudayaan Daerah sebagaimana dimaksud dalam Pasal 12 dapat dilaksanakan oleh pranata kebudayaan di Daerah.

(2) Pranata Kebudayaan sebagaimana dimaksud pada ayat (1) meliputi:

a. lembaga adat;

b. lembaga pengelola kebudayaan;

c. komunitas kebudyaan; dan

d. komunitas adat

Pasal 17

(1) Pemerintah Daerah bertanggungjawab dalam melakukan engembangan terhadap:

a. warisan sejarah dan kebudayaan daerah;dan

b. nilai-nilai tradisional yang berniiai luhur.

Berdasarkan gambaran dua pasal
Raperda di atas, dapat diketahui bahwa Provinsi Banten belum memiliki aturan khusus mengenai perlindungan masyarakat adat.

Lebak sebagai kabupaten di Provinsi Banten yang memiliki masyarakat adat Baduy dan Kasepuhan Banten Kidul. Kabupaten Lebak memiliki setidaknya memiliki dua Peraturan Daerah yaitu: 1) Perda Kabupaten Lebak No.32/2001 tentang Perlindungan atas Hak Ulayat Masyarakat Baduy dan 2) Perda Kabu-paten Lebak No. 8/2015 tentang Pengakuan, Perlindungan dan Pember-dayaan Masyarakat Hukum Adat Kasepuhan. Di tingkat Pemerintahan paling bawah, Desa Kanekes sudah memiliki Perdes No. 01/2007 tentang Saba Budaya dan Perlindungan Masyarakat Adat Tatar Kanekes (Baduy).

\section{Perda Kabupaten Lebak No. 32/2001 tentang Perlindungan atas Hak Ulayat Masyarakat Baduy}

Isi dari Perda Kabupaten Lebak No. 32/ 2001 mencakup: ketentuan umum; hak ulayat masyarakat baduy yang meliputi: penetapan hak ulaya dan pengecualian terhadap hak ulayat masyarakat baduy; batasbatas hak ulayat masyarakat baduy yang meliputi: batas desa dan batas alam, ketentuan pidana; ketentuan penyidikan; 
ketentuan lain-lain; dan ketentuan penutup.

Perda ini lahir atas inisiatif masyarakat Baduy karena dilatarbelakangi oleh beberapa faktor yaitu: 1) banyaknya penebangan dan pembalakan liar di wilayah/lahan Baduy oleh masyarakat luar Baduy; 2) pencurian hasil tanaman masyarakat Baduy oleh orang luar; dan 3) pergeseran batas wilayah yang dilakukan oleh orang luar di daerah perbatasan Baduy, yaitu Sobang, Muncang, Bojongmanik, dengan alasan bahwa tanah yang digarap itu milik negara.

Berdasarkan hasil wawancara dengan Jaro Baduy, Edih Mulyadi (tanggal 23/06/ 2016) sebelum Perda ini muncul, terdapat 17 titik lahan yang digarap oleh masyarakat luar yang sebenarnya itu adalah wilayah Baduy. Karena alasan dan permasalahan tersebut, masyarakat Baduy berusaha mengatasi masalaah tersebut bersama tokoh masyarakat Baduy di Desa Kanekes, Dinas Kehutanan, dan Kementrian Lingkungan Hidup, sampai ke Presiden Abdurahman Wahid.

Tahap awal yang dilakukan Jaro mendesak para tokoh adat agar segera bermusyawarah atas usulan pembuatan perda hak ulayat. Selanjutnya, Jaro Daenah bersama pejabat Desa, tokoh lembaga adat, melakukan koordinasi dengan Mentri Dalam Negeri (Yogi S. M.), Menteri Lingkungan Hidup (Erna Witular) hingga menghadap ke
Presiden. Hasil koordinasi mendapatkan respon yang baik hingga Perda hak ulayat terwujud.

Walaupun Perda sudah diundangkan namun implementasinya masih mengalami beberapa prmasalahanm diantaranya adalah: 1) sosialisasi masih minim, sehingga masih ada kasus penebangan, pembalakan liar, dan pencurian hasil hutan di wilayah perbatasan Baduy; dan 2) adanya kasus rencana pengeboran minyak di wilayah Baduy.

Perda Kabupaten Lebak No. 8/2015 tentang Pengakuan, Perlindungan dan Pemberdayaan Masyarakat Hukum

\section{Adat Kasepuhan}

Isi Perda Kabupaten Lebak No. 8/2015 terdiri dari: ketentuan umum; asas, tujuan, dan ruang lingkup; keberadaan dan kedudukan hukum kasepuhan; wilayah adat; hak masyarakat hukum adat kasepuhan; lembaga adat; hukum adat; pemberdayaan masyarakat hukum adat kasepuhan; penyelesaian sengketa; ketentuan penutup.

Berdasarkan hasil wawancara dengan informan kunci, pada umumnya masyarakat di Citorek sudah mengetahui perda No.8/ 2015 tentang Pengakuan, Perlindungan dan Pemberdayaan Masyarakat Hukum Adat Kasepuhan karena perda ini lahir dari tuntutan masyarakat Citorek dan masyarakat adat lainnya yang menginginkan hak-hak 
masyarakat adat terlindungi oleh negara.

Sebelum lahirnya Perda tersebut, Citorek hanya sebatas desa pada umumnya berbasis masyarakat adat. Dengan adanya Perda Masyarakat Adat, eksistensi masyarakat adat akan terjaga karena masyarakat adat berbeda dengan masyarakat desa pada umumnya. Salah satu perbedaan sistem pemerintahan masyarakat adat dengan sistem pemerintahan desa pada umumnya adalah dalam proses pemilihan Kepala Desa di mana masyarakat adat tidak mengikuti aturan pemilihan yang sudah ditetapkan pemerintah, tetapi berdasarkan sistem yang dibuat oleh masyarakat adat itu sendiri dan lembaga adat dikontrol oleh lembaga adat.

Salah satu faktor yang mendorong lahirnya Lahirnya Perda No.8/2015 adalah tumpang tindihnya pengeleloaan lahan antara masyarakat Citorek dengan Taman Nasional Gunung Halimun Salak. Pada mulanya Taman Nasional Halimun Salak tidak mencakup masyarakat adat. Namun, setelah dikeluarkannya SK Kemenhut No.

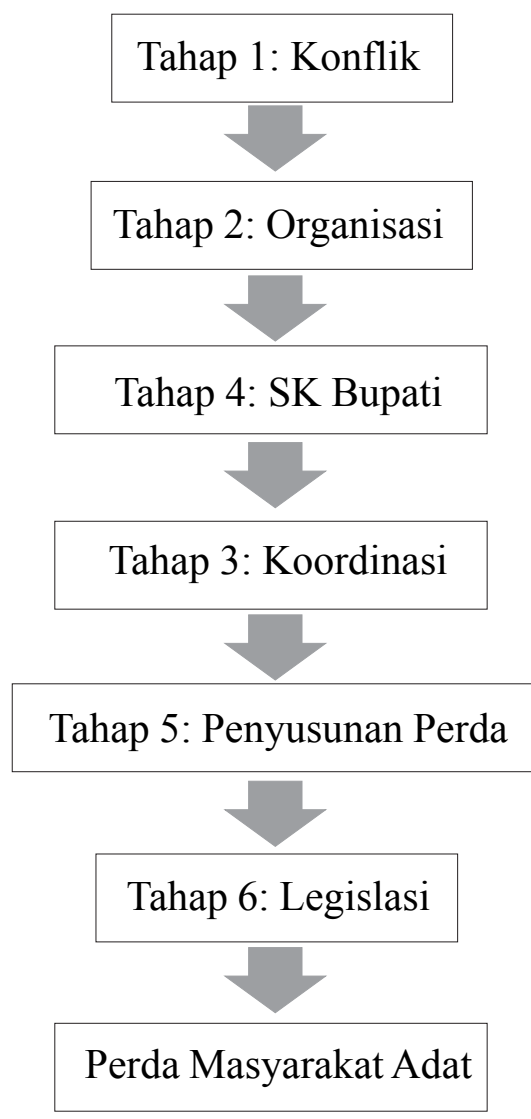

Gambar 1 : Tahapan Pembentukan Perda Masyarakat Adat 
175/Kpts-II/2003 tentang perluasan Taman Nasional Gunung Halimun Salak oleh pemerintah, luas Taman Nasional semakin melebar dan mencakup wilayah adat. Undang-Undang No.41/1999 tentang kehutanan menjelaskan bahwa "Hutan adat adalah Hutan Negara yang berada di Wilayah Masyarakat adat". Atas dasar undang-undang ini pihak Taman Nasional lebih leluasa dalam mengelola lahan, bahkan bisa menuntut masyarakat ke ranah hukum. Undangundang tersebut menimbulkan konflik di masyarakat, sehinga masyarakat mengajukan banding ke Mahkamah Konstitusi. Akhirnya MK merevisi poin dalam undang-undang tersebut yang disebut MK 35, yang berbunyi: "Hutan Adat adalah Hutan yang berada di Wilayah Masyarakat Adat".

Meskipun MK sudah merevisi undangundang tersebut, namun Citorek sebagai masyarakat adat belum diakui secara legal oleh pemerintah, karena berdasarkan undang-undang No.41/1999, dalam point yang lain, disebutkan bahwa keberadaan masyarakat adat ditentukan oleh pemerintah daerah. Berdasrkan itulah masyarakat Citorek mendorong pemerintah agar segera membuat perda tentang masyarakat adat.

Menurut narasumber (H. Ace) perda no.8/2015 tentang kasepuhan adalah perda yang sangat mahal karena proses pembuatannya memakan waktu yang sangat lama, sekitar 7 tahun (2009-2015). Orangorang yang terlibat dalam proses ini tidak hanya kelompok-kelompok elit, seperti pemerintah, organisasi adat, atau NGO, melainkan melibatkan semua unsur masyarakat dari semua kalangan dengan tahapan sebagai berikut.

\section{Harapan masyarakat adat terhadap kebijakan pemerintah Daerah}

Berdasarkan hasil wawancara dari responden, beberapa harapan yang disampaikan msyarakat adalah berkaitan dengan infrastruktur, sistem pemerintahan khusus di masyarakat adat, perlindungan tanah masyarakat adat, dukungan pengembangan upacara adat, dan perlindungan eksistensi masyarakat adat.

Masyarakat membutuhkan infrastruktur yang baik, terutama akses jalan. Diakuinya Citorek sebagai masyarakat adat, akan menjadi perhatian masyarakat dari luar. Akses yang mudah akan mendorong Citorek menjadi desa Wisata yang pada gilirannya dapat meningkatkan perekonomiannya masyarakat. Salah satu hak masyarakat yang juga harus dipenuhi adalah anggaran untuk Seren Taun dan pesta adat lainnya harus dianggarkan dari APBD. Masyarakat berharap jangan sampai ada kesan 
masyarakat mengemis kepada pemerintah meminta sumbangan untuk acara Seren Taun.

Selain itu, pemerintah juga harus memberikan otonomi kepada masyarakat adat dalam pemilihan Kepala Desa tidak melalui pemilihan kepala desa dengan pencoblosan, tetapi melalui musyawarah menurut adat. Menurut masyarakat adat Desa Citorek, pemilihan melalui sistem pemilu hanya akan menimbulkan disharmoni antar masyarakat. Dalam tradisi masyarakat Citorek, bagaimanapun perpecahan adalah hal yang sangat dilarang, masyarakat Citorek menjunjung tinggi nilai-nilai persaudaraan.

Berkaitan dengan masalah tanah adat, pemerintah juga harus membuat sertifikat khusus untuk hutan atau lahan yang dikelola masyarakat adat atas nama kasepuhan adat, bukan atas nama pribadi.

\section{KESIMPULAN DAN REKOMENDASI}

\section{Kesimpulan}

Secara umum, perhatian pemerintah daerah (Kab.Lebak) terkait masyarakat adat/ kasepuhan sudah dilakukan dengan mengeluarkan 2 Perda, yaitu:1) Perda Kabupaten Lebak No.32/2001 tentang Perlindungan atas Hak Ulayat Masyarakat Baduy; 2) Perda Kabupaten Lebak No. 8/ 2015 tentang Pengakuan, Perlindungan Dan Pemberdayaan Masyarakat Hukum Adat
Kasepuhan. Namun, Perda terkait masyarakat Baduy baru mengakomodir masalah hak ulayat, belum pada hal-hal lain yang sebenarnya sangat krusial dan perlu segera diatasi.

Dua Perda tersebut lahir dari aspirasi masyarakat karena berbagai permasalahan yang sebelumnya muncul. Masyarkat Baduy dan Masyarakat Kasepuhan Citorek secara umum menilai bahwa dua perda tersebut sudah membantu mengatasi permasalahan yang ada, walaupun dalam tataran teknis masih ditemui beberapa permasalahan.

Masyarakat adat/kasepuhan berha-rap ada Perda lain yang dapat mengatasi berbagai permasalahan yang muncul terkait masyarakat adat, dan pemerintah perlu proaktif mengawal Perda tersebut.

\section{Rekomendasi}

Berdasarkan hasil kajian atas kebijakan pemerintah daerah terkait perlindungan keberadaan masyarakat adat di wilayah Provinsi Banten, ada beberapa rekomendasi yang perlu kami sampaikan kepada pemerintah daerah:

1. Hendaknya Pemerintah Kabupaten Lebak segera membuat pedoman pelaksanaan kedua Perda tersebut

2. Pemerintah Kabupaten Lebak perlu proaktif mengawal dan mengontrol 
implementasi dari dua Perda tersebut.

3. Pemerintah Provinsi Banten perlu segera membuat Perda Masyarakat Adat yang dapat Mengatasi berbagai Permasalahan Masyarakat Adat.

\section{DAFTAR PUSTAKA}

Arizona, Y. 2016. Memahami Masyarakat Adat: Pendekatan Evolusionis versus Pluralis. Jakarta: Makalah FGD Perlindungan Konstitusional Masyarakat Hukum Adat P4TIK Mahkamah Konstitusi

Arizona, Y. 2010. Satu dekade legislasi masyarakat adat: Trend legislasi nasional tentang keberadaan dan hak-hak masyarakat adat atas sumber daya alam di Indonesia (1999-2009). dalam Arizona, Y. (Ed.). 2010. Antara teks dan konteks: Dinamika pengakuan hukum terhadap hak masyarakat adat atas sumber daya alam di Indonesia. Seri Hukum dan Keadilan Sosial, Aman: 15 -67 .

Bahar, S. 2008. Kebijakan Negara Dalam Rangka Pengakuan, Penghormatan, Dan Perlindungan Masyarakat [Hukum] Adat Di Indonesia. Jogjakarta: Pusat Studi Hak Asasi Manusia Universitas Islam Indonesia.

Buku Kepustakaan Online. 2017. http:// 20.unhamzah.web.id/id3/2822-2720/ Kasepuhan-Ciptagelar_138010_20unhamzah.html

Danasasmita, S. dan A. Djatisunda. 1984.
Kehidupan Masyarakat Desa Kanekes, Jakarta: Kemendikbud Direktorat Jendral Kebudayaan Proyek Penelitian dan Pengkajian Kebudayaan Nusantara (Javanologi).

Hakim, L. 2012. Baduy Dalam Selubung Rahasia. Serang: Biro Humas dan Protokol Setda Provinsi Banten

Iskandar, J. dan B. S. Iskandar. 2005. Pengobatan Alternatif Ala Baduy. Bandung: Humaniora

Iskandar, J \& R. Ellen. 1999. In situ conservatiom of rice landraces among the Baduy West Java. Journal of Ethnobiology 19(1): 97 - 125.

Nababan, A. 2009. Mengidentifikasi masyarakat adat di Indonesia: Pandangan dan pengalaman AMAN, makalah dipresentasikan dalam Konsultasi CSO-KLH,16 Oktober, 2009.

Permana, C. E. 2010. Kearifan Lokal Masyarakat Baduy dalam Mitigasi Bencana. Jakarta: Wedatama Widya Sastra.

Samosir, D. 2013. Hukum Adat Indonesia. Medan: CV. Nuansa Aulia.

Soekanto, S. 2012. Pengantar Penelitian Hukum. Jakarta: UI Press.

Sucipto, T. dan J. Limbeng. 2007. Studi Tentang Religi Masyarakat Baduy Di Desa Kanekes Provinsi Banten, Departemen Kebudayaan Dan Parawisata Direktorat Jendral Nilai Budaya Seni Dan Film Direktorat Kepercayaan Terhadap Tuhan Yang Maha Esa. 
Suganda, K.U. (2015). Komunitas Masyarakat Adat Kasepuhan Ciptagelar. Membangun Posisi Tawar Hak Atas Hutan Adat Hutan untuk Masa Depan Pengelolaan Hutan Adat di Tengah Arus Perubahan Dunia. 31 - 65 .

Suparmini, S. Setyawati, \& D. R. S. Sumunar. 2012. Pelestarian lingkungan masyarakat Baduy berbasis kearifan lokal. Laporan Penelitian Unggulan UNY. Yogyakarta: Fakultas Ilmu Sosial Universitas Negeri Yogyakarta

Toto Sucipto dan Julianus Limbeng. 2007. Studi Tentang Religi Masyarakat Baduy Di Desa Kanekes Provinsi Banten, Jakarta: Departemen Kebudayaan Dan Parawisata Direktorat Jenderal Nilai Budaya Seni Dan Film Direktorat Kepercayaan Terhadap Tuhan Yang Maha Esa.

Wahid, M. 2011. Sunda Wiwitan Baduya; Agama Penjaga Alam Lindung Di Desa Kanekes Banten, Hikmah Journal Of Islamic 8(1): 23 - 30 . 